dr inz. Vladimir Laptev

Instytut Naukowo-Badawczy

Transportu Kolejowego, Moskwa

dr inz. Marek Babel

Politechnika Krakowska

\title{
Filtracja magnetyczna wody chłodzącej zapobiegająca tworzeniu się osadów w ukladach chłodzenia silników spalinowych lokomotyw
}

\begin{abstract}
$W$ artykule zaprezentowano metode filtracji wody w układzie chtodzenia silników lokomotyw spalinowych poprzez zastosowanie aparatu magnetycznego, hydrocyklonu i zaworu regulacyjnego. Zastosowana metoda zapobiega powstawaniu osadów (kamienia kotlowego) i korozji na powierzchniach płaszczy wodnych tulei cylindrowych, przewodów wodnych i sekcji chtodzacych. Opisano procesy chemiczne i fizyczne zachodzace $w$ trakcie ciagtej filtracji wody chtodzacej. Zaprezentowano sposoby zabudowy zestawów filtrujacych w różnych układach chłodzenia silników lokomotyw spalinowych. Przedstawiono przyklady zabudowanych elementów układu filtracji na lokomotywach spalinowych wraz z wynikami eksploatacyjnymi efektywności filtracji wody chłodzacej.
\end{abstract}

\section{Magnetyczna filtracja wody chłodzącej.}

Kombinacja wody $\mathrm{z}$ różnymi domieszkami stosowana jest szeroko jako nośnik ciepła w układach chłodzenia silników spalinowych lokomotyw. Domieszki rozpuszczane $\mathrm{w}$ wodzie stosuje się w celu zapobiegania powstawaniu osadów i korozji w układzie silnika, przewodach i radiatorach układu chłodzenia. Jednakże dany sposób wymaga poniesienia w eksploatacji określonych kosztów związanych z przygotowaniem wody chłodzącej, dodawaniem drogich domieszek oraz ciągłą kontrolą jakości wody w czasie pracy silnika. W taki sposób przygotowana woda chłodząca jest nieprzyjazna dla środowiska przy jej utylizacji.
Specjaliści z dziedziny energetyki cieplnej i budowy lokomotyw opracowali nowy sposób walki z osadami i korozja poprzez zastosowanie aparatu magnetycznego, hydrocyklonu i zaworu regulacyjnego w układzie chłodzenia silnika spalinowego (rys. 1.). Układ filtracji zabudowany jest w gałęzi równoległej (przewodzie bocznikowym) do sekcji chłodzącej chłodnicy z możliwością regulacji ilości przepływającej wody chłodzącej przez aparat magnetyczny i hydrocyklon niezależnie od obrotów silnika spalinowego. Konstrukcja hydrocyklonu pozwala usuwać cząsteczki szlamu mniejsze niż 0,5 mikrona $\mathrm{z}$ wody chłodzącej, która posiada temperaturę od 70 do $80^{\circ} \mathrm{C}$ i określoną objętość, dla której obliczony (dobrany) jest hydrocyklon i aparat magnetyczny.

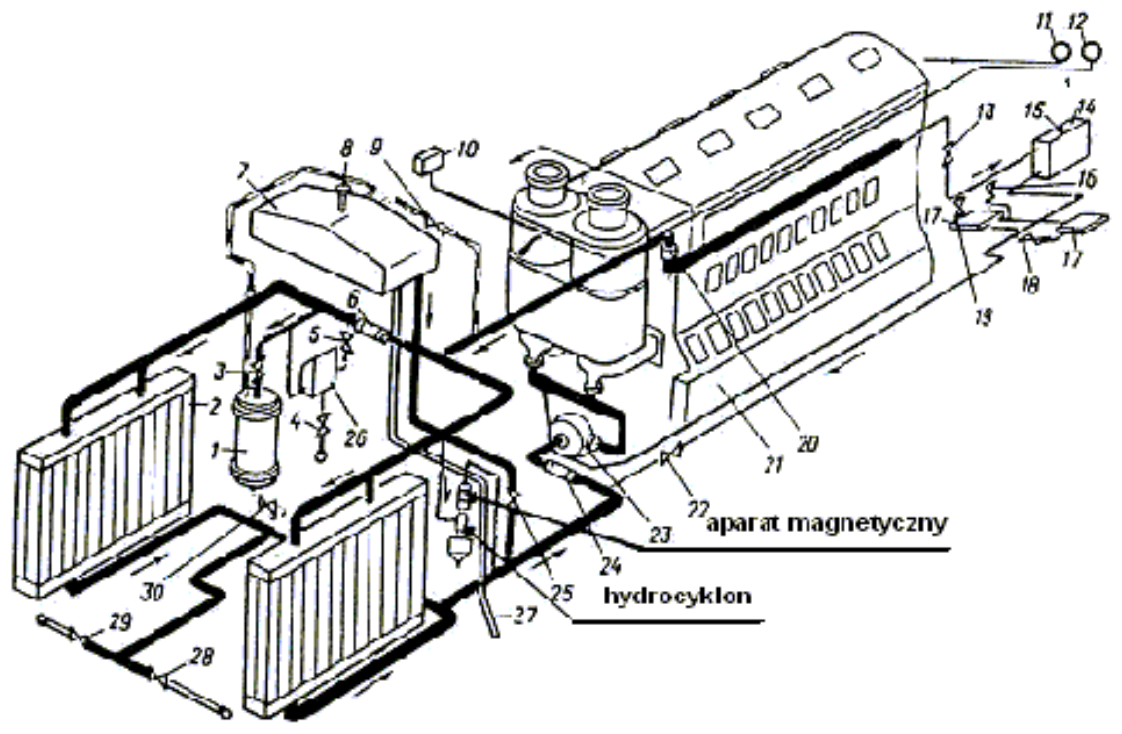

Rys.1. Jednoobiegowy układ chłodzenia lokomotywy spalinowej 1 -podgrzewacz paliwa; 2 -sekcje chłodzące; 3, 4, 5, 9, 13, 16, 18, 19, $22,25,28,29,30$-zawory; $6,20,24$ złączki elastyczne; 7 -zbiornik wyrównawczy; 8 zawór do napełniania; 10 -przekaźnik termiczny; 11, 12 termometry; 14 -nagrzewnica; 15 zawór odpowietrzający; 17 -grzejnik; 21 -silnik spalinowy; 23, 26 -pompy wodne; 27 -rurka spustowa 
Wiadomo, że wpływ pola magnetycznego na wyeliminowanie zjawiska tworzenia się osadów związany jest głównie $\mathrm{z}$ termodynamiczną utratą równowagi krystalicznych ciał stałych. Tworzenie się krystalicznych ciał stałych jest wynikiem zastosowanych domieszek do wody chłodzącej.

Przesycenie wody - soli osadotwórczych, przyspiesza proces tworzenia się i koncentracji krystalicznych ciał stałych. W wyniku działania sił odśrodkowych w hydrocyklonie krystaliczne cząsteczki ciał stałych odrzucane są na wewnętrzne jego ścianki i w wyniku zwiększenia ich koncentracji opadają do odstojnika. Należy zaznaczyć, że proces obróbki magnetycznej wody chłodzącej powinien odbywać się w sposób ciągły. W przeciwnym wypadku następuje zahamowanie procesu tworzenia się krystalicznych ciał stałych w wyniku czego, spada jakość separacji $\mathrm{w}$ hydrocyklonie. Zwiększenie koncentracji krystalicznych ciał stałych i powstanie efektu zapobiegającego tworzeniu się osadów jest wynikiem kontaktu wody $\mathrm{z}$ polem magnetycznym w układzie zamkniętym.

Prędkość strumienia $\mathrm{w}$ aparacie magnetycznym ma duże znaczenie, np., zwiększenie prędkości prowadzi do zwiększenia efektu tworzenia się krystalicznych ciał stałych i do zmniejszenia powierzchni wzajemnego kontaktu $\mathrm{z}$ upływem czasu. Z reguły, wybór optymalnej prędkości zależy od ilościowego składu domieszek w wodzie chłodzącej.

\section{Efektywność nowej metody.}

W wyniku długotrwałej pracy układu chłodzenia silników spalinowych lokomotyw, w którym wykorzystywana była woda bez domieszek i technologia filtracji magnetycznej, nie stwierdzono występowania śladów korozji lub osadów (kamienia kotłowego) na powierzchniach płaszczy wodnych tulei cylindrowych, przewodów wodnych i sekcji chłodzących. Powierzchnie tulei cylindrowych i przewodów wodnych były pokryte warstewką magnetytu $\gamma$ i $\alpha$ Fe3O4 o grubości mniejszej niż $4 \mu \mathrm{m}$, co potwierdza właściwości antykorozyjne. Utworzenie się magnetytu nastąiło w wyniku tego, iż pod działaniem siły elektromotorycznej $\mathrm{w}$ polu magnetycznym, cyrkulacja elektronów w układzie chłodzenia przyjęła określone kierunki, bardziej ujemne i równomierne. $\mathrm{W}$ wyniku polaryzacji powierzchni metalicznej, nastapiła częściowa przemiana tlenku żelaza lub rdzy w tlenek żelazawy, w rezultacie czego utworzył się magnetyt $\gamma$ i $\alpha$ Fe3O4.
W przypadku kiedy aparat magnetyczny był zabudowany w układzie chłodzenia silnika spalinowego $\mathrm{z}$ osadami na jego wewnętrznych elementach, uległy one rozpuszczeniu. Związane jest to z tym, że objętość powstałego magnetytu $\gamma$ i $\alpha$ Fe3O4, była mniejsza od objętości istniejącego tlenku żelaza lub rdzy. Pod wpływem ciepła, parowania wody i rozszerzania się gazów następuje w efekcie pęcznienie i stopniowe rozpuszczanie się osadów.

W próbkach wody, pobranych po przejściu strumienia przez aparat magnetyczny, stwierdzono występowanie cząsteczek o wymiarach od 0,5 do $5 \mu \mathrm{m}$. W odstojniku hydrocyklonu wymiary ich były mniejsze niż $120 \mu \mathrm{m}$. Wymiary zbadanych cząsteczek zestawiono $\mathrm{w}$ tablicy 1 poniżej.

\begin{tabular}{|l|c|c|}
\multicolumn{2}{|c}{ Wymiary cząsteczek zanieczyszczeń } & Tab.1 \\
\hline Badany odcinek & $\begin{array}{c}\text { Wymiary } \\
\text { czasteczek, } \mu m\end{array}$ & $\begin{array}{c}\text { Sktad } \\
\text { procentowy } \\
\text { próbki }\end{array}$ \\
\hline Za aparatem & 0,5 & 15 \\
magnetycznym & 1,0 & 15 \\
& $2,0-3,0$ & 50 \\
Za hydrocyklonem & $4,0-5,0$ & 20 \\
\hline \multirow{5}{*}{ W odstojniku } & $0,5-1,0$ & 80 \\
hydrocyklonu & $4,0-3,0$ & 10 \\
& 40,0 & 10 \\
\hline
\end{tabular}

W czasie pracy silnika spalinowego lokomotywy w okresie 24 godzin, cała objętość wody w układzie chłodzenia przepływa przez aparat magnetyczny i hydrocyklon około 24 - 35 razy. Jest to w pełni wystarczające, aby usunąć osady i wtrącenia metaliczne z układu chłodzenia.

\section{Zabudowa elementów zestawu filtracji wody $w$ układzie chlodzenia.}

Wymagania dotyczące zabudowy aparatu magnetycznego i hydrocyklonu są następujące:

1. Jeżeli układ chłodzenia jest jednoobiegowy, to aparat magnetyczny i hydrocyklon należy zabudować zgodnie ze schematem przedstawionym na rys. 1 .

2. Jeżeli układ chłodzenia jest dwuobiegowy (obieg główny - chłodzenie tulei cylindrowych; obieg pomocniczy - chłodzenie oleju), to aparat magnetyczny i hydrocyklon należy zabudować $\mathrm{w}$ każdym obiegu - rys. 2, uwzględniając następujące czynniki: 




Rys.2. Dwuobiegowy układ chłodzenia lokomotywy spalinowej

1, 3 -sekcje chłodzące; 2 -zawór; 4 -chłodnica obiegu głównego; 5 -chłodnica chłodzenia oleju; 6 -podgrzewacz paliwa; 7 -zbiornik wyrównawczy; 8 -zawór bezpieczeństwa; 9 -wskaźnik poziomu wody; 10 -pompa ręczna; 11 -złączki; 13,14 czujniki temperatury; 15 -termometr; 16 -chłodnica powietrza; 17, 19 -zawory powietrzne; 18 -wymienniki ciepła; 20 -pompa wodna; 22, 46 -zawory obiegu głównego i pomocniczego; 10, 15, 17, 21, 24, 25, 27, 28, 32, 33, 37, 41, 47, 48, 53, 57 zawory

2.1. W przypadku stałego połączenia pomiędzy dwoma obiegami, kiedy zawór łączący obydwa obiegi jest otwarty, a twardość wody wynosi mniej niż $6 \mathrm{mg} / \mathrm{l}$, aparat magnetyczny i hydrocyklon należy zainstalować na jednym $\mathrm{z}$ dwóch obiegów. Jeżeli twardość wody jest większa niż 6 $\mathrm{mg} / \mathrm{l}$, aparat magnetyczny i hydrocyklon należy zainstalować na obydwu obiegach.

2.2. W przypadku braku połączenia pomiędzy obydwoma obiegami, kiedy zawory 22 i 46 są zamknięte (rys. 2), aparat magnetyczny i hydrocyklon należy zainstalować na obydwu obiegach niezależnie od twardości wody.

a)

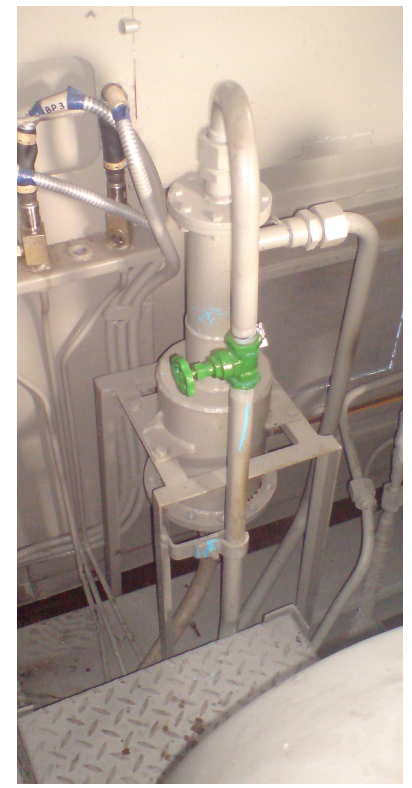

b)

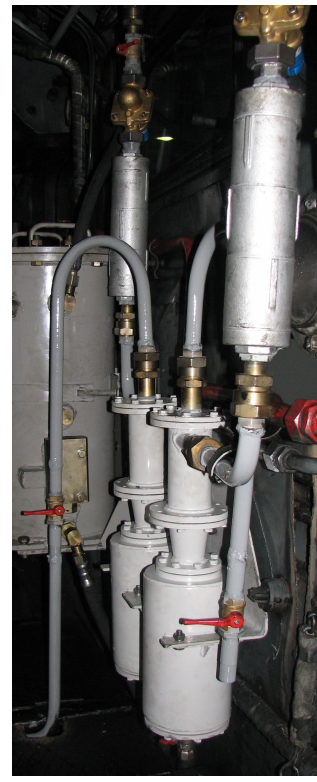

Rys. 3. Zabudowa elementów zestawu filtracji wody na lokomotywach spalinowych

a) lokomotywy serii 2TE116; b) lokomotywy 2TE10
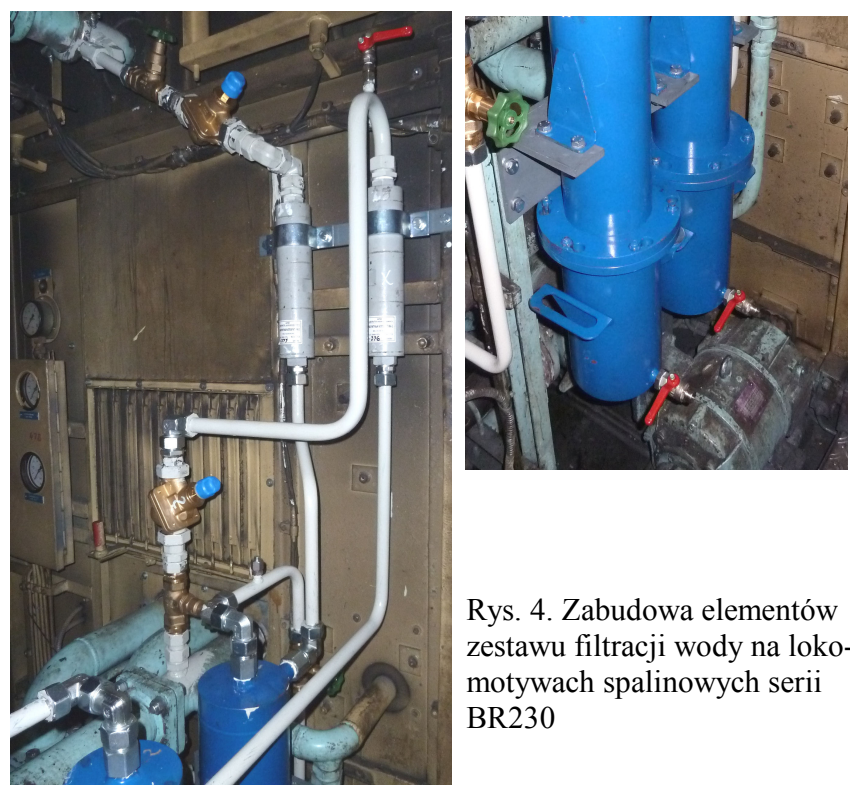

Rys. 4. Zabudowa elementów zestawu filtracji wody na lokomotywach spalinowych serii BR230

\section{Wnioski.}

1. Wyniki eksploatacji nadzorowanej lokomotyw spalinowych z zabudowanymi układami magnetycznej filtracji wody chłodzącej, a następnie wieloletnie doświadczenia $\mathrm{z}$ eksploatacji seryjnej lokomotyw, potwierdziły efektywność zastosowanej metody filtracji. Lokomotywy spalinowe wyposażane są $\mathrm{w}$ trakcie planowych ich napraw w przedmiotowe zestawy filtracji wody chłodzącej - rys. 3, 4 . 
2. W trakcie planowych przeglądów kontrolnych P1 lokomotyw, przeprowadzanych co 30 dni, odbywa się regularne opróżnianie odstojnika szlamu. Ustalono, na podstawie danych eksploatacyjnych, że w trakcie opróżniania odstojnika na P1 usuwanych jest średnio od 50 do $80 \mathrm{~g}$,twardego" szlamu z układu chłodzenia silnika spalinowego lokomotywy.
3. W układzie wodnym lokomotyw serii SM48 zabudowywany jest jeden zestaw filtra magnetycznego; na lokomotywach serii ST44, w tym zmodernizowanych z silnikiem spalinowym CN26/26, montowane są dwa zestawy, jak przedstawiono na rys. 4. 